\title{
ARTYKUtY
}

Klio. Czasopismo poświęcone dziejom Polski i powszechnym

PL ISSN 1643-8191, t. 50 (3)/2019, s. 65-83

(c) (1) $\Theta$

http://dx.doi.org/10.12775/KLIO.2019.037

Wioletta ZielecKa-MiKOŁAJCZYK"

\section{Próby integracji prawosłaunej społeczności diecezji przemyskiej wokół obrony prawosławia w latach 1596-1610}

\section{Attempts to integrate the Orthodox community of the Przemyśl diocese around the defence of Orthodoxy in the years 1596-1610}

Streszczenie: Artykuł stanowi próbę ujęcia działań prawosławnych w obronie swej wiary w latach 1596-1610, tj. od ogłoszenia unii brzeskiej do pojawienia się w Przemyślu pierwszego unickiego władyki przemyskiego Atanazego Krupeckiego. Do śmierci obóz prawosławny popierał magnat Aleksander Ostrogski. Ortodoksom udało się przeforsować postulaty obrony prawosławia na sejmiku wiszeńskim w 1597 i 1603 roku. W obronie swych praw występowali ruscy mieszczanie Przemyśla i Sambora. Na wypadek śmierci władyki Kopysteńskiego zabiegano o zatrzymanie władyctwa w rękach prawosławnych. Próby integracji wyznawców prawosławia dotyczyły raczej lokalnych niewielkich środowisk, korporacji zawodowych albo zachodziły w ramach stanu społecznego. Nie stworzono

* Uniwersytet Mikołaja Kopernika w Toruniu, ul. Gagarina 11, 87-100 Toruń, zielecka@umk.pl, ORCID: https://orcid.org/0000-0001-6100-0563. 
w omawianym okresie silnego ruchu zabiegającego o obronę prawosławia. Możliwości integrowania się środowiska przemyskich prawosławnych ograniczała jego słaba pozycja polityczna i ekonomiczna.

Abstract: This article attempts to establish an account of the activities of believers of the Orthodox Church in defence of their faith in the years 1596-1610, i.e. from the announcement the Union of Brest to the appearance in Przemyśl of the first Uniate bishop of Przemyśl, Athanasius Krupecki. Magnate Alexander Ostrogski, until his death, supported he Orthodox camp. Orthodox believers managed to push through the demands for the defence of the Orthodoxy at the diet in Sacdowa Wisznia in the years 1597 and 1603. The Ruthenians of Przemyśl and Sambor defended their rights. In case of the death of bishop Michael Kopysteński, efforts were made to stop the bishopric rule in the hands of the Orthodox Church. Attempts to integrate Orthodox believers were made in rather small local communities, professional associations or within the social groups. During the period in question, Orthodox believers didn't create strong movement to defend the Orthodox Church. The possibilities of the integration of the Orthodox community were limited by weak political and economic position.

Słowa kluczowe: diecezja przemyska, prawosławie, unia brzeska, integracja

Keywords: diocese of the Przemyśl, Orthodox Church, Union of Brest, integration

$\mathrm{D}$ zieje diecezji przemyskiej przełomu XVI i XVII wieku już niejednokrotnie wzbudzały zainteresowanie historyków Cerkwi wschodniej, którego rezultatem jest między innymi, powstała jeszcze u schyłku XIX wieku, praca Antoniego Dobriańskiego poświęcona biskupom przemyskim zarówno prawosławnego, jak i unickiego obrządku oraz badania Antoniego Prochaski ukazujące, tylko przez pryzmat materiałów z ksiąg sądowych, konflikt prawosławno-unicki na terenie eparchii ${ }^{1}$. W latach osiemdziesiątych minionego stulecia spod pióra zmarłego niedawno Mariana Bendzy wyszła monografia poświęcona dziejom ortodoksyjnej eparchii przemyskiej w latach 1595-1681, która, pomimo znacznej stronniczości w ujęciu dziejów wyznaniowych dawnej Rzeczypospolitej, uchodzi za podstawową wy-

1 A. Dobrjańskij, Istoria episkopow trech sojedinennych eparchij Peremyszlskoj, Samborskoj, Sanockoj od najdawniejszych wremion do 1791 g., Lvov 1893. 
kładnię wiedzy na temat historii eparchii przemyskiej ${ }^{2}$. W ostatnich latach ukraiński badacz Leonid Tymoszenko zainteresował się sytuacją wytworzoną wokół katedry św. Jana w Przemyślu w czasie negocjacji poprzedzających zawarcie unii brzeskiej ${ }^{3}$. Beata Lorens zbadała zaangażowanie przemyskich bractw cerkiewnych oraz sytuację wyznaniową na sejmiku wiszeńskim, jednak w odniesieniu do zjazdów szlachty województwa ruskiego swoje rozważania na dobre rozpoczęła dopiero od 1603 roku$^{4}$. Natomiast Jacek Krochmal podjął się eksploracji materiałów pozwalających na identyfikację osób tworzących unickie środowisko eparchii przemyskiej w okresie sporów prawosławno-unickich oraz ukazanie procesu powstawania parafii uznających zwierzchność Stolicy Apostolskiej5. Skład osobowy wiernych prawosławnych oraz ich próby integracji w obronie wiary, w okresie bezpośrednio następującym po unii brzeskiej, w pierwszych latach działalności w Przemyślu unickiego biskupa Atanazego Krupeckiego, tj. do 1614 roku, kiedy po powrocie z Węgier rozpoczął formowanie administracji cerkiewnej, pozostaje wciąż mało znany. Warto także zwrócić uwagę na czynniki wpływające na możliwości integracyjne przemyskich prawosławnych.

Diecezja przemyska była najdalej wysuniętą na zachód eparchią Kościoła prawosławnego w dawnej Rzeczypospolitej. Jej granice rozciągały się na ziemię przemyską i sanocką, zachodnie krańce ziemi lwowskiej, wdzierała się w obszar województwa bełskiego, obejmując Lubaczów wraz z jego okolicami. Na południowym zachodzie w jej skład wchodziły: powiat sądecki i biecki województwa krakowskiego, starostwo spiskie, sięgając aż po południowo wschodnie tereny województwa sandomierskiego. Południowe

2 M. Bendza, Prawostawna diecezja przemyska w latach 1596-1681. Studium historyczno-kanoniczne, Warszawa 1982; idem, Tendencje unijne względem cerkwi prawostawnej w Rzeczypospolitej w latach 1674-1686, Warszawa 1987.

3 L. Tymoszenko, Peremiszlska prawostawna eparchia i uktadennja Berestejskoj unii, „Fasciculi Musei Regionalis Brzozoviensis” 2011, nr 5, s. 15-31.

${ }^{4}$ B. Lorens, Prawostawie i unia w eparchii przemyskiej na forum sejmiku wiszeńskiego $w$ XVII w., [w:] Śladami unii brzeskiej, red. R. Dobrowolski, M. Zemło, Lublin - Supraśl 2010, s. 37-62.

5 J. Krochmal, Duchowieństwo unickie eparchii przemysko-samborskiej w latach 1596-1609, „Miscellanea Historico-Archivistica” 2013, t. 20, s. 135-167; idem, Kaptani uniccy w eparchii przemysko samborskiej za rzadów biskupa Atanazego Krupeckiego (1610-1652), „Miscellanea Historico-Archivistica” 2014, t. 21, s. 137-170. 
krańce diecezji, obejmujące Beskid Zachodni i Bieszczady, stanowiły jednocześnie granicę państwa polsko-litewskiego ${ }^{6}$. Wierni i duchowieństwo zamieszkujący górzyste tereny eparchii w oczywisty sposób mieli ograniczone możliwości w docieraniu do centrum życia duchowego eparchii. Często uzależnieni od pory roku, warunków pogodowych nie byli w stanie dotrzeć do cerkwi.

Diecezja przemyska funkcjonowała w warunkach poganiacza kulturowego, na który zasadniczo składały się żywioł polski, wyznający rzymski katolicyzm, i ruski, należący do Cerkwi prawosławnej. Osadnictwo ludności ortodoksyjnej nie było równomierne na całym terytorium diecezji. Bardziej intensywnie przebiegało na jej południowych i wschodnich terenach, tj. w rejonie Sambora, Drohobycza, Stryja. Osadnictwo ruskie traciło na intensywności na kierunku północno-zachodnim ${ }^{7}$ gdzie dominowali rzymscy katolicy, a parafie obrządku wschodniego były stosunkowo mniej liczne, liczące nawet po kilkanaście osób. Najdalej wysunięte na zachód były dobra muszyńskie biskupów krakowskich, którzy prowadzili w nich kolonizację wołoską i ruską w XVI wieku, oraz parafie: Szlachtowa, Litmanowa, Jarembina, Kamionka, Jakubiany ${ }^{8}$.

Nie bez znaczenia dla zaangażowania wiernych w działalność na rzecz prawosławia pozostawały podziały społeczne i ekonomiczne regionu. Południowo-zachodnie obszary zamieszkiwała głównie prawosławna ludność włościańska zależna od decyzji kolatorów, tj. biskupów krakowskich, monarchy albo rzymskokatolickiej szlachty. Brakowało tu przedstawicieli prawosławnej szlachty, która miała większe możliwości oddziaływania politycznego. Jej najważniejsi przedstawiciele zajmowali centralne i wschodnie tereny eparchii. Najbardziej wpływowe prawosławne rody to Lityńscy, Kopysteńscy, Popiele, Chłopeccy, Bolestraszyccy, Turzańscy. Była to jednak, w przeciwieństwie do mecenatu katolickiego i protestanckiego, stanowiącego elitę majątkową i polityczną regionu (Krasickich, Herburtów,

6 S. Nabywaniec, Diecezja przemyska greckokatolicka w latach 1772-1795, Przemyśl 1992, s. 31.

7 Z. Budzyński, Ludność pogranicza polsko-ruskiego w drugiej potowie XVIII wieku. Stan. Rozmieszczenie. Struktura wyznaniowa i etniczna, Przemyśl-Rzeszów 1993, s. 79.

8 W. Bębynek, Starostwo muszyńskie - wtasność biskupstwa krakowskiego, Lwów 1914, s. $16-19$. 
Drohojowskich, Stadnickich, Lubomorskich, Mniszchów), średniozamożna, jedno- lub dwuwioskowa, szlachta częściej zorientowana na kwestie majątkowe i podatkowe niż wyznaniowe. Jedynym przedstawicielem ruskiej magnaterii był Aleksander Ostrogski, syn ostoi ortodoksji w Rzeczypospolitej Konstantego Ostrogskiego, ożeniony z właścicielką dóbr jarosławskich Anną Kostkówną.

Mieszczaństwo ruskie zasilało przedmieścia miast ziemi przemyskiej i sanockiej, rekrutowało się zwykle spośród kuśnierzy, mularzy, krawców9 Skutecznie jednak animowało życie religijne, skupiając się w bractwach cerkiewnych, czyli laickich organizacjach skoncentrowanych m.in. na patronacie religijnym, finansowaniu przycerkiewnej edukacji wiernych. Skupiały one wokół siebie ruskich mieszkańców Gródka, Jarosławia, Komarna, Przemyśla, Sądowej Wiszni, Starej Soli. Ich działalność naświetlają badania m.in. Jarosława Isajewycza i Beaty Lorens ${ }^{10}$.

W najbliższych miesiącach po synodzie unia nie wywołała większej reakcji środowisk prawosławnych eparchii, ponieważ i wiedza o niej była znikoma. W przestrzeni publicznej województwa zaistniała ona na sejmiku wiszeńskim w styczniu 1597 roku, gdzie obradowała szlachta ziemi przemyskiej, sanockiej i lwowskiej. Tutaj Aleksander Ostrogski na polecenie ojca Konstantego zabiegał o wsparcie dla prawosławia przez umieszczenie odpowiednich zapisów w instrukcji sejmikowej. Konstanty Ostrogski włączył do tych działań władykę lwowskiego Gedeona Bałabana oraz przedstawicieli ruskiego mieszczaństwa ${ }^{11}$. Brakuje jednak dowodów na podję-

9 J. Motylewicz, Spoteczności unickie $w$ miastach województwa ruskiego $w$ XVII i XVIII wieku, [w:] Polska - Ukraina. Tysiąc lat sąsiedztwa, red. S. Stępień, t. 4, Przemyśl 1998, s. 191.

10 J. Isajewycz, Bratstwa ta ich rol w rozwitku ukrainskoj kultury XVI-XVII st., Kiiv 1966; B. Lorens, Bractwa cerkiewne eparchii przemyskiej, Rzeszów 2005, s. 310-316; eadem, Bractwa cerkiewne w Przemyślu w XVII i XVIII wieku, „Fasciculi Musei Regionals Brzosoviensis" 2009, nr 4, s. 23-41; eadem, Cerkiewne szkoty brackie w eparchii przemyskiej w XVI-XVIII wieku, „Rocznik Komisji Nauk Pedagogicznych” 2004, t. 57, s. 5-21; eadem, Konfraternie cerkiewne diecezji przemyskiej w XVII i XVIII wieku, [w:] Cywilizacja prowincji Rzeczypospolitej szlacheckiej, red. A. Jankowski, A. Klonder, Bydgoszcz 2004, s. 213-227.

11 K. Chodynicki, Kościót prawostawny a Rzeczpospolita Polska w l. 1370-1632, Warszawa 1934 , s. 336. 
cie w tym czasie jakichkolwiek kroków w tej sprawie przez ortodoksyjne mieszczaństwo diecezji przemyskiej. Bardziej prawdopodobna wydaje się obecność wysłanników konfraterni lwowskiej. Brakuje danych o udziale w sejmiku władyki Kopysteńskiego, choć w przeciwieństwie do katolickich biskupów i arcybiskupa lwowskiego nie podpisywał laudów sejmikowych, to trudno sobie wyobrazić, że go tam nie było.

Spośród przemyskiej prawosławnej szlachty w sejmiku zimą 1597 roku udział wzięli członkowie bardzo rozrodzonego na Przemyślszczyźnie rodu Popielów, gdyż w instrukcji sejmikowej postulowano rewizję należących do nich żup solnych ${ }^{12}$. Byli obecni i inni członkowie przemyskiej ortodoksji, ponieważ protestowali przeciwko szkodom wyrządzonym przez stacjonujące w regionie wojska hetmańskie. Dzień po zakończeniu sejmiku 21 stycznia szlachta przemyska wniosła protest w tej sprawie do ksiąg grodzkich przemyskich ${ }^{13}$. Spośród prawosławnych protestację podpisali: Iwan Popiel, Marcin Rytarowski, Teodor Popiel, brat władyki przemyskiego Aleksander Kopysteński, który wyraził poparcie także w imieniu kolejnego z braci Jachna Kopysteńskiego ${ }^{14}$. Wśród sygnatariuszy protestu znalazł się także Michał Lityński, ojciec żony władyki przemyskiego Anny, a także inni członkowie prawosławnych rodów, m.in.: Iwan i Marcin Błażowscy, Fedko Waczowicz Matkowski, Wasko Czernieczki, Piotr Malawski Filipowicz, Andrzej Ustrzycki, Wasyl, Łukasz, Maciej Lityński, Waśko Winnicki, Piotr Ortyński, Hryczko Totamir, Staś Bereznicki, Iwan Turzański ${ }^{15}$.

Jak wiadomo, sejmik w styczniu 1597 roku został zdominowany przez lokalne konflikty między magnaterią a szlachtą o naciski wojska przy wyborze składów poselskich, co było związane z rywalizacją o wpływy senatorów

12 Dyaryusze sejmowe z roku 1597, wyd. E. Barwiński, Kraków 1907, s. 388.

13 „pp. postom naszym od nas tj. rycerstwa zgodnie obranym zlecilismy to i zlecamy, aby J. kr. Mć imieniem nas obywatelów ziem województwa tego uniżenie prosili, aby J. kr. Mć, te żotnierze, które IMć p. hetman w krajach naszych potożyt, ex nunc znieść $i$ takowa niewole $z$ nas ztożyć mitościwie raczyt $i$ nas obywatelów i nas z tej opressyej wyjąt", Akta grodzkie i ziemskie z czasów Rzeczypospolitej Polskiej z archiwum tak zwanego bernardyńskiego we Lwowie (dalej: AGZ), t. 20, s. 103-104.

14 I. Smutok, Kopistinski u peremiszl'slkoj zemli w XVI-XVIII st., Genealogiczne doslidżennja, „Genealogiczni Zapiski” 2011, vyp. 9, s. 54.

15 AGZ, t. 20, cz. 1, s. 104; Dyaryusze sejmowe z roku 1597, s. 390-391. 
popierających Jana Zamoyskiego i Stadnickich, stronników Zborowskich. Spodziewano się eskalacji konfliktu majątkowego między Janem Tomaszem Drohojowskim a Aleksandrem Ostrogskim ${ }^{16}$. Ostatecznie zbuntowana przeciw obozowi magnackiemu szlachta doprowadziła do rozdwojenia sejmiku. Stronnictwo szlacheckie ze Stanisławem Stadnickim „Diabłem z Łańcuta” przeniosło się na cmentarz, podczas gdy reszta obradowała w kościele $^{17}$. Kwestie poruszane przez prawosławnych zostały zawarte w instrukcji wypracowanej przez stronnictwo senatorskie, co wskazywałoby na to, że pozostali oni przy części obradującej w kościele. W instrukcji żądano: „ludzie religiej greckiej albo ruskiej, aby przy swych ceremoniach zostawieni byli, oprócz kalendarza, na którym siła należy krajom ruskim dla poddanych i jarmarków. Jednak do Turek do swych patriarchów ani patriarchowie tu do nich nie mają posłańców posyłać bez wiadomości J. Kr. Mci, a to dla uchronienia się od szpiegów nieprzyjacielskich" ${ }^{18}$. Choć kolejność postulatów ujmowanych w instrukcjach sejmikowych nie zawsze świadczy o ich wadze dla lokalnej społeczności szlacheckiej, to w przypadku sejmiku wiszeńskiego z 1597 roku zwraca uwagę fakt, że problem religii greckiej wśród 50 problemów dotyczących Rzeczypospolitej wymieniono jako dziewiąty, zaraz za kwestiami najważniejszymi, tj. przystąpieniem do ligi antytureckiej, zapobieganiem hamowaniu obrad sejmowych, umocnieniem obrony Krakowa i kwestii kozackiej. Za nią wymienia się np. ujętą w legacji królewskiej kwestię obrony zamków ukrainnych. Bardzo ważne dla szlachty województwa ruskiego postulaty umocnienia obrony Lwowa, Halicza, Przemyśla, Sambora, Żydaczowa umieszczono dopiero w trzeciej dziesiątce. Skuteczność działania szlachty można uznać za połowiczny sukces, ponie-

16 J. Rzońca, Spór o prawomocność wyboru postów wiszeńskich na sejmie 1597 r., „Zeszyty Naukowe Wyższej Szkoły Pedagogicznej w Opolu, Historia” 1986, t. XXIII, s. 14.

17 Idem, Sejmy z lat 1597 i 1598, cz. 1: Bezowocny sejm z 1597 roku, Warszawa-Wrocław 1989, s. 23-32.

18 Centralnyj Dierżawnyj Istoricznij Archiv Ukraini Lviv (dalej: CDIAUL), f. 13, op. 1, spr. 313, s. 76-85; AGZ, t. 20: Akta sejmikowe wiszeńskie 1572-1648, t. 1, Lwów 1931, s. 100. Już podczas sejmu Stanisław Stadnicki z Ożomli podał marszałkowi instrukcję woj. ruskiego „od szlachty”, ale nie wiadomo, jakie postulaty się w niej znalazły. Poznanie jej pomogłoby określić, czy zwrócono uwagę na sprawę prawosławia; Dyaryusze sejmowe z roku 1597, s. 96; por. K. Chodynicki, Kościót prawostawny..., s. 363-364. 
waż nie zdołała włączyć swego przedstawiciela do składu poselskiego, który ostatecznie zdominowali katolicy, tj. klient Zamoyskiego Jan Tomasz Drohojowski, referendarz koronny, starosta przemyski, także nękający władykę Kopysteńskiego najazdami na jego dobra, do tego katolik tym gorliwszy, że wcześniej zasilał grono wyznawców protestantyzmu ${ }^{19}$. Podobnie było z regalistą Janem Krasickim z Siecina oraz posłami z ziemi sanockiej, Janem Stanisławem Mniszchem, starostą sanockim, czy Stanisławem Wapowskim, synem Katarzyny Wapowskiej ${ }^{20}$.

Sprawa obrony prawosławia znalazła się wśród postanowień sejmiku wiszeńskiego z 1598 roku. Niestety, nie wiemy nic o udziale w nim innych przedstawicieli ortodoksji oprócz Aleksandra Ostrogskiego, któremu ojciec polecił wspierać prawosławie na sejmiku ruskim ${ }^{21}$. Najpewniej zadziałał scenariusz sprzed roku. Obawiano się również, że posłowie podczas sejmu moga priorytetowo potraktować sprawy religii kosztem ważniejszych dezyderatów umieszczonych $\mathrm{w}$ instrukcji ${ }^{22}$. Taką możliwość sugerował skład poselski, do którego wszedł klient Konstantego Ostrogskiego - Jan Swoszowski, a także protestant Stanisław Stadnicki ze Żmigrodu. Również Piotr Bal z ziemi sanockiej pochodził z rodziny od lat związanej z protestantyzmem²3. Być może wybór ten był efektem wspólnej działalności ruskiej

19 K. Lepszy, Drohojowski Jan Tomasz, PSB 1949-1956, t. 5, s. 383.

20 K. Przyboś, Reprezentacja sejmowa ziemi przemyskiej w latach 1573-1695, „Rocznik Przemyski” 1998, t. 36, z. 4, s. 28-30.

21 T. Kempa, Wobec kontrreformacji. Protestanci i prawostawni w obronie swobód wyznaniowych w Rzeczypospolitej w końcu XVI i w pierwszej potowie XVII wieku, Toruń 2007, s. 141.

22 „A iż się uskarżają Ich Mci Panowie Bracia naszej diversereligionis, stroną niedochodzenia krzywd swoich, przeto starać się o to PP posłowie mają, aby za zgodą y uważeniem wszech stanów koronnych ta rzecz na tym sejmie koniecz swoj wziąć mogła. Wprzód jednak tej rzeczy nie puszczając, przed wyżej pisane artykuły także Ich Mci panowie bracia naszy Religie jgreczkiej, jakoby naruszenia prawa swego w religiej nie ci[er]pieli i dekreta ich by się pokazały przeciwko prawu starać się mają PP. Posłowie, aby były zniesione ex Cognitionis", Archiwum Główne Akt Dawnych w Warszawie (dalej: AGAD), AR II, nr 377, s. 2.

23 Był synem Stanisława Bala z Hoczwi, który wprowadził tam protestantyzm. Linia Balów pochodząca od brata Stanisława - Macieja, przez 100 lat trwała jeszcze przy protestantyzmie. Piotr Bal w 1615 r. był już katolikiem, T. Śliwa, Diecezja przemyska w połowie XVI w., Przemyśl 2015, s. 244. Wśród posłów znaleźli się podkomorzy Andrzej Sienieński 
szlachty i protestantów, stanowiącej początek sojuszu ukierunkowanego na obronę swobód wyznaniowych w Rzeczypospolitej? Niestety, brak źródeł uniemożliwia ostateczną odpowiedź na to pytanie.

Prawosławni skutecznie jednak przeciwdziałali zwolennikom unii, których aktywność popierał przemyski biskup łaciński Wawrzyniec Goślicki, przekonany o prawie do koordynowania sprawy jedności Kościołów wschodniego i zachodniego na terenie swojej diecezji. Kiedy w maju 1598 roku w Sanoku tamtejszy paroch Erazm Dubiecki, chcąc wprowadzić unię, popadł w konflikt z prawosławnym mieszczaństwem, które pozbawiło go dochodów z beneficjum, nazwało „lachem” i „łacinnikiem”24. Biskup Goślicki ogłosił go unickim namiestnikiem sanockim. Choć w wyniku działalności Dubieckiego, jak przypuszcza Zbigniew Budzyński, zanikły w Przemyślu konwersje prawosławnych na rzymski katolicyzm, to niezaprzeczalny pozostaje fakt, że żadne inne źródła nie wspominają o aktywności tego duchownego, co wskazywałoby na jej epizodyczny charakter ${ }^{25}$.

z Sienna na Gołogorach, Andrzej Fredro z Chodnowicz, ziemi sanockiej Marcin Stadnicki ze Żmigrodu na Rymanowie, AGAD, AR II, nr 377, s. 1.

${ }^{24}$ CDIAUL, f. 15, op. 1, nr 23, k. 2548; A. Prochaska, $Z$ dziejów unii brzeskiej, „Kwartalnik Historyczny” 1896, R. 10, s. 568; W. Sarna, Biskupi przemyscy obrzadku tacińskiego, cz. 1: 1375-1624, Przemyśl 1903, s. 216; J. Krochmal, Catholic-orthodox Relations in the Diocese of Przemysl in the Fourteenth-Eighteenth Centuries, Lithuania and Ruthenia. Studies of a Transcultural Communication Zone (15 Rohdewald, David Frick, Stefan Wiederkehr, Wiesbaden 2007, p. 225.

${ }^{25}$ Z. Budzyński, Ludność parafii przemyskiej obrzadku tacińskiego w świetle rejestrów metrykalnych z lat 1592-1635, Struktura demograficzna, „Przemyskie Zapiski Historyczne” 1989 , t. 6-7, s. 111. Za zbyt daleko idące należy uznać poglądy Jacka Krochmala, który na podstawie przywileju nominacyjnego na namiestnictwo sanockie wystawionego przez biskupa Goślickiego zaliczył Erazma Dubieckiego do „wybitniejszych postaci eparchii przemysko-samborskiej”. Badacz przypuszczał, że Dubiecki miał świadomość konieczności zreformowania Cerkwi, a „egzamin” przeprowadzony przez łacińskiego biskupa uznał z pewną dozą ostrożności za pozytywne świadectwo wykształcenia tego duchownego. Tymczasem nic nie wiemy ani o osobie Dubieckiego, jego motywach przejścia na unię, ani o charakterze przeprowadzonego „egzaminu”. Być może o powierzeniu mu namiestnictwa sanockiego zadecydowała właśnie wierność unii, a nie wykształcenie. Motywy przyjęcia unii nie miały jedynie charakteru wyboru religijnego. Czasem były to decyzje dość pragmatyczne. Jako dowód może posłużyć przypadek Bartłomieja Zaszkowskiego, który po ekskomunice nałożonej na niego przez przemyskiego władykę Michała Kopysteńskiego 
Na pewno nie przetrwała ona do objęcia władzy w diecezji przez pierwszego unickiego biskupa przemyskiego Atanazego Krupeckiego, ponieważ nie znajdujemy go wśród jego najbliższych współpracowników. Gdyby w środowisku przemyskiej katedry łacińskiej istniał namiestnik trzymający pieczę nad wiernymi unickimi, zapewne poparłby nowego rządcę diecezji, pełniąc przy nim ważne funkcje. Tymczasem wiemy, że Krupecki organizował struktury swej władzy od podstaw ${ }^{26}$. W próżnię trafiły klątwy nałożone na władykę Kopysteńskiego przez biskupa Goślickiego, zakazujące wiernym prawosławnym uznawania jego zwierzchnictwa ${ }^{27}$.

Władyka Kopysteński w pierwszych latach po ogłoszeniu unii brzeskiej nie zabierał głosu w publicznej debacie dotyczącej obrony prawosławia pomimo tego, że po przyjęciu unii przez większość hierarchii Kościoła wschodniego stał się po Gedeonie Bałabanie, patriarszym egzarsze, drugą osobą w Cerkwi prawosławnej w Rzeczypospolitej. Przyczyn postawy Kopysteńskiego można doszukiwać się w konflikcie z metropolitą Michałem Rahozą, sposobie życia władyki, który będąc mnichem bazyliańskim, pomimo napomnień, mieszkał przy katedrze przemyskiej z żoną Anną ${ }^{28}$. Nie bez znaczenia pozostawała obawa o swój los w nowej i trudnej sytuacji Kościoła prawosławnego. Wiadomo, że Kopysteński zajmował się głównie sprawami majątkowymi i procesami w obronie dóbr cerkiewnych i prywatnych ${ }^{29}$.

przyjął unię i został protopopem w Wilnie, J. Krochmal, Duchowieństwo unickie w eparchii przemysko-samborskiej w latach 1596-1910, „Miscellanea Historico-Archivistica” 2013, t. 20 , s. 165.

${ }^{26}$ J. Krochmal, Kaptani uniccy w eparchii przemysko-samborskiej za rządów biskupa Atanazego Krupeckiego (1610-1652), „Miscellanea Historico-Archivistica” 2014, t. 21, s. $147-148$.

27 A. Dobrjańskij, Istoria episkopów trech sojedinennych eparchij..., s. 5; A. Mironowicz, Kościót prawostawny w dziejach dawnej Rzeczypospolitej, Białystok 2001, s. 69; W. Sarna, Biskupi przemyscy obrzadku tacińskiego..., s. 216; S. Nabywaniec, Diecezja przemyska obrządku wschodniego w okresie sporów prawostawno-unickich, [w:] Polska-Ukraina. 1000 lat sąsiedztwa. Studia z dziejów grekokatolickiej diecezji przemyskiej, Przemyśl 1996, red. S. Stępień, t. 3, s. 40.

${ }^{28}$ L. Sonevickij, Ukrainski episkopat Peremiskoj i Cholmskoj eparchii v XV-XVI w., „Zapiski Naukovogo Tovaristva im. Tarasa Ševčenka” 1982, t. 202, s. 39-40.

${ }^{29}$ CDIAUL, f. 13, op. 1, spr. 63, c. 1028 1031; ibidem, spr. 313, s. 1169-1171; ibidem, spr. 316, s. 807-809, 820-828, 863-864; ibidem, spr. 319, s. 16. 
Działał aktywnie na niwie życia wewnętrznego Cerkwi, o czym świadczy dobrze znany w historiografii list Zygmunta III z 22 marca 1599 roku, krytykujący Kopysteńskiego i Bałabana za wkraczanie w cudze diecezje, wyświęcanie kapłanów, organizowanie zjazdów, które utrudniają wprowadzanie unii ${ }^{30}$. Zwraca uwagę fakt, że biskup nie pojawił się osobiście ani nie posłał swych przedstawicieli na zjazd prawosławnych i protestantów do Wilna w początkach czerwca 1599 roku, gdzie omawiano współpracę między obu wyznaniami w obronie konfederacji warszawskiej. Także przez kolejne dwa lata brak informacji o jego zaangażowaniu w obronę prawosławia i próbach organizowania w tej sprawie wiernych.

Zarówno bierność Kopysteńskiego, jak i słabość wpływów szlachty prawosławnej na sejmiku wiszeńskim spowodowała, że w 1600 roku postulaty obrony prawosławia nie znalazły się w instrukcji dla posłów województwa ruskiego ${ }^{31}$. Wobec tego wierni diecezji działali samodzielnie. W wyniku ich starań 31 marca 1600 roku, tuż po niekorzystnych dla prawosławia postanowieniach sejmu, na którym król uznał unitów za jedynych legalnych wyznawców Kościoła wschodniego w państwie polsko-litewskim, potwierdzone zostały przywileje statutów cechów ruskich przemyskich szewców ${ }^{32}$.

Ruska szlachta wiązała nadzieje na poprawę sytuacji prawosławia podczas sejmu 1603 roku. W czasie sejmiku zdołano przeforsować do instrukcji postulat w obronie wiary greckiej. Szlachta, wątpiąc jednak w skuteczność poselskich zabiegów podczas sejmu, obwarowała swe żądanie protestacją złożoną w księgach grodzkich przemyskich 28 stycznia 1603 roku. Blisko 100 przedstawicieli ruskiej prawosławnej szlachty, krytykując bezowocność dotychczasowych starań posłów województwa ruskiego, a także innych „zacnych wielu osób” o swobodę odprawiania kultu, używania i obsadzania cerkiewnych beneficjów, groziło, że w przypadku kolejnej porażki na

30 K. Chodynicki, Kościót prawostawny..., s. 372; S. Nabywaniec, Diecezja przemyska obrzadku wschodniego..., s. 40.

31 T. Kempa, Wobec kontrreformacji..., s. 177.

32 Akta Miasta Przemyśla, oprac. J. Krochmal, s. 89; Archiwum Państwowe w Przemyślu (dalej: APP), Akta Miasta Przemyśla, sygn. 97D; P. Żukowicz, Sejmowaja borba prawosławnogo zapadno-russkogo godworjanstwa s cerkownojunijej do 1609, Sankt Petersburg 1901, s. 394-397; K. Chodynicki, Kościót prawostawny..., s. 374; T. Kempa, Wobec kontrreformacji..., s. 183. 
sejmie w tej spawie odmówią respektowania jego postanowień, w tym także regulacji poborowych ${ }^{33}$. Wśród protestujących nie było władyki Michała i blisko z nim współpracującego syna Teodora, ale ich szeregi zasilili trzej bracia hierarchy Jachny, Aleksander, Hrycko oraz syn Andrzej. Jednocześnie biskup Kopysteński zabiegał u króla o potwierdzenie katedrze przemyskiej św. Jana przywileju na wieś Szehinie, a także zwolnienie od wszelkich obciążeń podatkowych. Król Zygmunt III przychylnie odniósł się do próśb władyki w ostatnich dniach sejmu (1 marca) ${ }^{34}$. Decyzji tej towarzyszyły inne ustępstwa władcy wobec ortodoksji, podyktowane potrzebą pozyskania szlachty dla planów interwencji w Moskwie. Zniesiono banicję archimandryty monasteru żydyczyńskiego Gedeona Bałabana oraz pozwolono szlachcie kijowskiej i kryłosowi na wybór archimandryty monasteru pieczerskiego $^{35}$.

W kolejnych miesiącach bardziej aktywie prezentowała się działalność prawosławnych na lokalnym terenie. 12 stycznia 1604 roku w Przemyślu mieszczanie religii greckiej wspólnie wystąpili do magistratu ze skargą na władze miasta, które rzekomo wydały cechowi kramarzy dokument zabraniający przyjmowania w szeregi organizacji wyznawców religii greckiej i wcielały jego postanowienia w życie. Rada miasta faktycznie zamierzała wydać takie rozporządzenie. Plan skrytykowała część ławicy miejskiej, wskazując na jego znaczną szkodliwość dla ruskich mieszkańców miasta. W nieznanych okolicznościach przystawiono pieczęcie do dokumentu. Władze Przemyśla w odpowiedzi skarżącej się stronie potępiły próby dyskryminacji Rusinów, podkreślając ich zasługi i przychylność wobec Rzeczypospolitej,

33 Protestację składali członkowie rodów m.in. Błażowskich, Chłopeckich, Ustrzyckich, Lityńskich, Popielów, Radyłowskich, Rytarowskich, Winnickich, Manasterskich, Sozańskich, Nehrebeckich, Terleckich, AGZ, t. 20, nr 62, s. 105-106; B. Lorens, Prawostawiei unia..., s. 39-40.

34 APP, Archiwum Biskupstwa Greckokatolickiego w Przemyślu (dalej: ABGK), sygn. 71D; ibidem, 47 supl., s. 24.

35 A. Mironowicz, Kościót prawostawny w dziejach dawnej Rzeczypospolitej, Białystok 2001, s. 71; T. Kempa, Wobec kontrreformacji..., s. 197-198. 
przywołano przywileje królewskie zabezpieczające ich prawa, a także wyrażono chęć zachowania pokoju między wyznaniami w mieście ${ }^{36}$.

Także w Samborze w końcu kwietnia 1604 roku prawosławni mieszkańcy przedmieść musieli mobilizować się przeciwko rzymskim katolikom, którzy oskarżali ich o to, że wraz ze swym władyką podburzają do tumultów okolicznych mieszkańców, w tym szlachtę, i niesłusznie oskarżają katolików o odcięcie dzwonu oraz zagarnięcie cerkiewnych utensyliów z jednej z samborskich cerkwi. Strona katolicka poświadczyła, że rzekomo skradzione naczynia liturgiczne widziano w cerkwi podczas pogrzebu jednej $\mathrm{z}$ mieszczanek ${ }^{37}$. Z tego też powodu sprawa została umorzona. Być może te wydarzenia związane były ze sporem między katolikami a prawosławnymi w Samborze, ciągnącym się od czasów władyki Radyłowskiego, któremu królowa Bona, właścicielka starostwa samborskiego, zezwoliła na budowę cerkwi w granicach Nowego Sambora w zamian za wybudowanie przez ruskich mieszczan fragmentu muru miejskiego koło cerkwi. Cerkiew powstała, natomiast nie zbudowano muru ${ }^{38}$.

Przykładem braku jedności przemyskich ortodoksów w sprawach wyznaniowych był okres rokoszu Zebrzydowskiego. Lokalne interesy, a przede wszystkim konieczność zabezpieczenia przed zagrożeniem tatarskim, sprawiały, że ruska brać szlachecka w większości pozostała lojalna wobec króla. Środowisko to uwikłane w zależności klientalne było podzielone. Wśród szlachty sejmiku wiszeńskiego w okresie rokoszu króla poparli przedstawiciele ortodoksyjnych rodzin Błażowskich i Brześciańskich. 31 lipca 1606 roku podpisali oni laudum sejmikowe popierające króla ${ }^{39}$. Pozostała

36 APP, ABGK, sygn. 47 supl., s. 52-53; Borotba Piwdenno-Zachidnoj Rusi i Ukraini protiekspansij Watikanu ta unij (X-poczatok XVII st.), upor. E.A. Griniw, Kiiv, nr 134, s. $186-188$.

37 CDIAUL, f. 13, nr 319, s. 622-623.

38 L. Smutok, Ruska gromada Nowogo Sambora u XV-XVIII st., „Drogobickij krajeznawczij zbirnik" 2009 , t. 9, c. 120 . Spór o podobnym charakterze trwał także w samym Przemyślu.

39 AGZ, 20: Akta sejmikowe wiszeńskie 1572-1648, t. 1, Lwów 1931, nr 76, s. 117. 
szlachta regionu także popierała władcę, o czym świadczą m.in. lauda sejmikowe, zarówno te z lutego, jak i z lipca 1606 roku $^{40}$.

Biskup Kopysteński wykorzystał rokosz do podniesienia problemu krzywd zadanych prawosławiu od czasu zawarcia unii brzeskiej. W liście z 1 czerwca 1606 roku do rokoszan podkreślał krzywdy ponoszone przez prawosławie, negował legalność działalności unijnej Pocieja i Terleckiego. Dostrzegał łamanie praw ortodoksji zarówno w Koronie, jak i w Wielkim Księstwie Litewskim. Podkreślał, że środowiska prawosławne wspólnie zabiegały na sejmikach, aby w laudach umieszczano postulat obrony i uregulowania spraw religii greckiej przez króla. Zabiegi te nie odnosiły żadnego skutku, a wręcz pogarszały sytuację ortodoksji w wyniku nacisków na prawosławnych inspirowanych przez Hipacego Pocieja. Biskup przemyski potępiał praktyki „po władicze zmarłym ktoby posłuszeństwa Kościoła zachodniego bycz nie chciał przywileju na władictwo ani władicstwa na ostatek i popowstwa popom nie dają" ${ }^{31}$. Podawał w wątpliwość słuszność duchownych mianowanych na parafie. Uważał, że zarówno Pociej, jaki i jego środowisko są podejrzani pod względem moralnym, czego dowodzi nominacja na biskupstwo połockie.

W swym liście Kopysteński zarzucał Pociejowi, że skutecznie zabiegał u wielu ktitorów cerkwi w eparchii przemyskiej, doprowadzając do tego, że siłą ,popów swoich w władictwie moim gwałtem i musem do posłuszeństwa tegoż Księdza metropolity prziwiedli. Cerkwi też Boże pieczętuje i zabrania chwałę Bożą wedle starego zwyczaju Cerkwie Świętej odprawowacz, skąd wielky a nigdy niesłychany rozruch i niemiłoscz między krzescziany urosła”. Oskarżał Metropolitę o przysyłanie do jego diecezji swych wysłanników, którzy „wielkie zamieszanie, i nienawiscz między ludźmi duchownemi i świckiemi, tudzież przeszkodę władzy mej duchownej czinicz nie przestają"42. Twierdził, że praktyki Pocieja świadczą bardziej o chęci konfrontacji niż o woli rozwiązania sprawy prawosławia pokojowo. Ostatec-

40 AGZ, t. 20, nr 71-76, s. 112-117; Biblioteka Narodowa w Warszawie, Zakład rękopisów, rkps. III.3087, s. 2023, 2033-2036.

41 Biblioteka PAN w Kórniku, rkps. 289, s. 265. Druk: B. Maciejowski, Piśmiennictwo polskie, Warszawa 1852, dodatki do t. 3, s. 223-226.

42 Biblioteka PAN w Kórniku, rkps. 289, s. 265. 
znie prosił rokoszan o wstawiennictwo w obronie przywilejów i praw prawosławnej ludności Rzeczypospolitej, w tym możliwości swobodnego odprawiania nabożeństw. Władyka z powodów choroby nie pojechał pod Lublin osobiście, a wysłał swych przedstawicieli ${ }^{43}$. List biskupa nie jest tylko apelem o obronę prawosławia, ale także dowodem jego dobrego i aktualnego rozeznania w aktualnej sytuacji Cerkwi i działalności prawosławnych. Dokument ten był ostatnim publicznym akordem działalności hierarchy na rzecz obrony prawosławia.

Pod uchwałą wzywającą rokoszan pod Sandomierz podpisali się dyzunici przemyscy i bliscy współpracownicy Kopysteńskiego: Iwan Popiel, Jan Chłopecki, zabiegający o katedrę św. Jana Chrzciciela po śmierci Arseniusza Brylińskiego, a także Tomasz Chłopicki. Wśród posłów wysłanych do króla pod Wiślicę znajdował się Mikołaj Popiel, prawdopodobnie pochodzący z diecezji przemyskiej ${ }^{44}$. List władyki do rokoszan, a także poparcie jego najbliższego środowiska dla buntu przeciw królowi mogą sugerować, że działano z pobudek o charakterze wyznaniowym.

Po artykułach wiślickich, uznających prawa prawosławia w Rzeczypospolitej, a także w latach wygaszania rokoszu zarówno przemyski biskup prawosławny, jak i wierni zaniechali zaangażowania w sprawy obrony wiary. Kopysteński zachował prawa do władyctwa aż do swojej śmierci na przełomie lutego i marca 1609 roku. W początkach 1609 roku władyka nie był już zbyt aktywny także w sprawach majątkowych i finansowych. Wydaje się, że już w pierwszej połowie lutego Kopysteński chorował na tyle poważnie, że duchowieństwo przemyskie obawiało się o losy tronu

43 T. Kempa, Prawostawni wobec rokoszu Zebrzydowskiego, [w:] Homo doctus in se semper divitias habet. Księga pamiątkowa ofiarowana Profesorowi Januszowi Mattkowi z okazji siedemdziesiatej rocznicy urodzin i pięćdziesięcioletniej rocznicy rozpoczęcia pracy naukowej, red. W. Polak, Toruń 2008, s. 270; A. Strzelecki, Udziat i rola różnowierstwa w rokoszu Zebrzydowskiego (1606-1607), „Reformacja w Polsce” 1935/1936, t. 7/8, s. 101-184, 130; A. Prochaska, Województwo Ruskie wobec rokoszu Zebrzydowskiego, „Przewodnik Naukowy i Literacki: Dodatek Miesięczny do Gazety Lwowskiej” 1908, R. 36, s. 962.

44 Biblioteka Narodowa, rkps. III.3087, s. 867-868. Ród Popielów był bardzo rozrodzony w ziemi przemyskiej. Osób o imieniu Mikołaj było zapewne wielu. Jeden z nich podpisywał się w księdze ziemskiej przemyskiej po polsku, co było rzadkością. Nie wiadomo, czy był to ten sam Mikołaj Popiel z rokoszu, CDIAUL, f. 14, op. 1, spr. 178, s. 119. 
władyczego. Między 15 stycznia a 26 lutego 1609 roku w Warszawie obradował sejm rozstrzygający nie tylko sprawy problemów porokoszowych, kwestię zagrożenia ze strony cara moskiewskiego Wasyla IV Szujskiego, ale także status prawosławia w Rzeczypospolitej. Po tym właśnie sejmie prawosławni spodziewali się pozytywnych rozstrzygnięć na rzecz swego wyznania. Do Warszawy zjechali przedstawiciele duchowieństwa i szlachty obu obrządków. Spośród spraw wyznaniowych, na których rozwiązanie liczono na sejmie, był spór metropolity Hipacego Pocieja z odmawiającym mu posłuszeństwa wileńskim duchowieństwem obrządku wschodniego ${ }^{45}$. $Z$ tego też powodu znalazła się tam liczna reprezentacja bractwa św. Trójcy, wileńskiego mieszczaństwa, a także przywódcy zbuntowanego unickiego duchowieństwa, wciąż mianujący się archimandrytą monasteru św. Trójcy Samuel Sieńczyłło, wileński protopop Bartłomiej Zaszkowski, pochodzący z ziemi przemyskiej, a także starszy prawosławnego bractwa św. Ducha Arnolf Wyrzykowski ${ }^{46}$. Zaszkowski duchowne wykształcenie zdobył właśnie w szkołach diecezji przemyskiej, a potem nauczał w przycerkiewnej szkole w Jarosławiu ${ }^{47}$. Choć ostatecznie trafił na łono Cerkwi unickiej po ekskomunice nałożonej na niego przez Michała Kopysteńskiego, teraz w okresie konfliktu z Pociejem i zbliżenia z obozem prawosławnym mógł stać się naturalnym sprzymierzeńcem dyzunickich Przemyślan ${ }^{48}$.

Z dwoma ostatnimi podczas sejmu spotkali się wysłańcy z Przemyśla duchowni Dymitr i Onokifor, którzy zrelacjonowali sytuację w diecezji.

T. Kempa, Wydarzenia wileńskie z lat 1608-1609, „Przegląd Wschodni” 2010, t. 11 , z. 3 , s. 471 .

46 Ibidem, s. 468.

47 Ibidem, s. 462.

${ }^{48}$ Związki Zaszkowskiego z Przemyślem wspominano już po zakończeniu konfliktu w Wilnie, kiedy musiał on szukać schronienia w Słucku, mieście Janusza Radziwiłła, podczaszego litewskiego, gdzie został kaznodzieją. Zyskał ponoć nawet przychylność wiernych, wzbudzając zazdrość protopopa Mirona Tefilaktowicza. W obronie Zaszkowskiego stanęło prawosławne bractwo wileńskie (św. Ducha), które w liście do bractwa w Przemyślu informowało, że Miron może zabiegać o listy oczerniające Zaszkowskiego i prosiło o lojalność wobec niego, AP w Przemyślu, ABGK, 28 supl., s. 20-21; zob. też: T. Kempa, Protopop stucki Andrzej Mużtowski - antagonista unii brzeskiej, [w:] Od Kijowa do Rzymu. $Z$ dziejów stosunków Rzeczypospolitej ze Stolica Apostolska i Ukraina, red. M.R. Drozdowski, W. Walczak, K. Wiszowata-Walczak, Białystok 2012, s. 747. 
17 lutego Sieńczyłło i Wyrzykowski odpisywali bractwu i duchowieństwu katedry św. Jana, deklarując podjęcie starań wspólnie z prawosławnym biskupem lwowskim Jeremiaszem Tyssarowskim, Elizeuszem Pletenickim archimandrytą pieczerskim oraz innymi przedstawicielami prawosławia w celu przeciwdziałania oddaniu władyctwa przemyskiego w ręce unitów ${ }^{49}$. W liście nie ma żadnej informacji o biskupie Kopysteńskim. Zapewne właśnie wobec słabego zdrowia biskupa, a także przewidując, że w obliczu jego śmierci rozpocznie się walka o obsadzenie władyctwa, przemyskie duchowieństwo zabiegało o wsparcie u swych współwyznawców. Przemyślanie pytali także o przebieg sejmu, ponieważ $\mathrm{w}$ odpowiedzi Sieńczyłł z Wyrzykowskim pisali, że intensywność obrad sejmu nie pozwala mu szczegółowo go opisać, dlatego wszystko, co konieczne, przekażą im posłańcy ${ }^{50}$. Warszawski epizod przemyskich duchownych z punktu widzenia badań nad diecezją przemyską ma bardzo istotne znaczenie, ponieważ dotychczas ustalono jedynie, że obóz prawosławnych zabiegał o pozostawienie władyctwa w rękach prawosławnych, natomiast brakowało dowodów troski o jego losy wśród duchowieństwa i wiernych eparchii ${ }^{51}$. Inicjatywa zabiegów o zatrzymanie władyctwa w rękach prawosławnych w świetle opisanych wydarzeń wyszła wcześniej niż jesienią 1609 roku i poprzedziła wątek szlacheckiego kandydata z ziemi przemyskiej Jana Chłopeckiego oraz jego rywalizację o nominację na rządcę katedry św. Jana z unitą Atanazym Krupeckim.

Śmierć biskupa Kopysteńskiego i powierzenie władyctwa Atanazemu Krupeckiemu „ożywiły” prawosławnych przemyskich do wystąpienia na szeroką skalę w obronie swych praw do wyboru władyki i przeciw instrumentalnemu potraktowaniu przez Zygmunta III konstytucji sejmowej z 1607 roku. Szlachta zaproponowała Jana Chłopeckiego na biskupa przemyskiego, a wobec pominięcia tej kandydatury przez króla zabiegała u niego o pozostawienie władyctwa w ręku prawosławnych, a także prosiła o wstawiennictwo u władcy kasztelana krakowskiego Janusza Ostrogskiego,

49 Wydarty koniec wersu, AP w Przemyślu, ABGK, 28 supl., s. 19.

50 Ibidem, s. 19.

51 List Hipacego Pocieja do Lwa Sapiehy, 1609 r. (spisany już po sejmie), Archeograficzeskij Sbornik Dokumentow, t. 6, ASD, t. 6, nr 77, s. 163. 
syna nieżyjącego już wówczas księcia Konstantego. Konflikt o władyctwo przemyskie nabrał wymiaru walki zbrojnej o dobra władycze i rząd dusz, w której obie strony wykazywały się brutalnością i bezwzględnością. Wyrazem takich praktyk były wydarzenia na sejmiku wiszeńskim w 1610 roku, gdzie ortodoksyjna szlachta i duchowieństwo znieważyła władykę Krupeckiego ${ }^{52}$. Ten atak na tle wyznaniowym był największym w omawianym okresie zbiorowym wystąpieniem prawosławnej szlachty w obronie władyctwa.

Dalsza część konfliktu o władyctwo przemyskie jest dość dobrze znana w historiografii. Natomiast wątkiem pomijanym jest udział duchowieństwa namiestniczego. Wiadomo, że w początkowej fazie konfliktu wraz ze szlachtą przeciwko biskupowi unickiemu wypowiedzieli się kapłani z najbliższego otoczenia zmarłego biskupa Kopysteńskiego: namiestnik przemyski Demetry Sidorski, namiestnik dubiecki Demetry Burda, a także kryłoszanie: Piotr Juriewski (Jurowski), Iwan Mikoliński, Teodor Totamir, Tomasz (Foma lub Toma) „prezbiter” i Jakub - diakon ${ }^{53}$. Nie posiadamy natomiast informacji o reszcie namiestników spośród 30 protopopii. Dane sądowe ukazują ich większą liczbę w gronie przeciwników Krupeckiego dopiero w 1614 roku, kiedy to nowy władyka pozywał niepokornych kapłanów do Trybunału Lubelskiego. Zatem na pewno już wcześniej dali wyraz swemu sprzeciwowi wobec nowego eparchy. W 1614 roku nie uznawali władzy Krupeckiego namiestnicy: jarosławski Konstanty, stryjski Michał, drohobycki Piotr Terlecki, nowosamborski Jakim, starosamborski Jakub, starosolski Andrzej, dobromilski Tymek, lubaczowski Prokop, jaworowski Żuhaj, gródecki Jan Popiel, rybotycki Tymofiej. Ponadto władzy Krupeckiego nie uznali namiestnicy o nieznanych personaliach, tj. medycki, sądowowiszeński, sanocki, krynicki i leski ${ }^{54}$. Ponieważ struktura protopopii eparchii przemyskiej dla początków XVII wieku pozostaje niezbadana, trudno dokładnie określić,

52 A. Prochaska, Wtadyka Krupecki $w$ walce z dyzunia, „Przegląd Powszechny” 1918, R. 35, s. 733-734; B. Lorens, Prawostawie i unia..., s. 43.

53 Biblioteka im. Wasyla Stefanyka (Lwiw), f. 5, nr 3862/III, k. 15-16. Pewną wątpliwość budzą nazwiska Juriewski i Mikoliński, które przypisano duchownym ze względu na cerkwie, które im podlegały. Być może Juriewski był prezbiterem cerkwi św. Jerzego na przedmieściu Garbarze w Przemyślu, a Mikoliński lub Nikoliński księdzem przy świątyni na Podgórzu w Przemyślu.

54 CDIAUL, f. 13 , op. 1, spr. 330, s. 841-846, 872-875, 899-900. 
jaka część duchowieństwa namiestniczego wystąpiła przeciwko Krupeckiemu. Jeśli jednak jako orientacyjne dane przyjmiemy te z końca XVII stulecia, traktujące o 31 protopopiach, nowego biskupa nie uznała ponad połowa kleru namiestniczego.

Próby integracji wyznawców prawosławia dotyczyły raczej lokalnych niewielkich środowisk, korporacji zawodowych albo zachodzity w ramach stanu społecznego. Nie stworzono w omawianym okresie silnego ruchu zabiegającego o obronę prawosławia. Możliwości integrowania się środowiska przemyskich prawosławnych ograniczała jego słaba pozycja polityczna i ekonomiczna. Prawosławni podejmowali wspólne działania przede wszystkim w poczuciu zagrożenia o pozycję i przywileje swojej wiary po ogłoszeniu unii brzeskiej i wprowadzeniu unickiego władyki na katedrę św. Jana w Przemyślu. Przy czym na przykładzie rozstrzygnięć 1603 roku wyraźnie widać, że wtedy, kiedy inicjatywa obrony pozycji ortodoksji uzyskała poparcie duchowieństwa i wiernych, przynosiła konkretne korzyści. 
